\title{
EKSTRAKSI ABU VULKANIK GUNUNG SINABUNG UNTUK MENGHASILKAN SILIKA GEL
}

\section{EXTRACTION VOLCANIC ASH OF SINABUNG MOUNT SILICA TO PRODUCTION SILICA GEL}

\author{
Maulida, Melva Ginting, Herlinawati Wici \\ ${ }^{1}$ Departemen Teknik Kimia, Fakultas Teknik, Universitas Sumatera Utara, \\ Jalan Almamater,Medan, 20155, Indonesia \\ Email: melvaginting79@gmail.com
}

\begin{abstract}
Abstrak
Silika gel merupakan salah satu material berbasis silika. Penelitian ini bertujuan untuk memanfaatkan abu vulkanik Gunung Sinabung menjadi silika gel dengan metode ekstraksi. Abu vulkanik diekstraksi dengan $\mathrm{NaOH} 4 \mathrm{M}$ dengan variasi waktu 30 menit, 60 menit, 90 menit dan 120 menit. Untuk pembentukan gel dilakukan dengan penambahan $\mathrm{HCl}$ dengan variasi konsentrasi 4M, 6M dan 8M. Karateristik dan analisa yang dilakukan pada penelitian ini ialah dengan FTIR, SEM-EDX, XRD, gravimetri dan AAS. Pada analisa larutan natrium silika dengan variasi waktu diperoleh kandungan silika tertinggi terdapat pada waktu ekstraksi 120 menit. Berdasarkan hasil karateristik dengan FTIR menunjukkan adanya gugus Si pada abu vulkanik dan adanya gugus Si-O-Si yang berhasil dibuat dari ekstraksi abu vulkanik. Berdasarkan hasil karateristik dengan SEM-EDX diperoleh bahwa kandungan silika pada silika gel dari abu vulkanik Gunung Sinabung sebesar 51,96\%. Berdasarkan hasil karateristik dengan XRD menunjukkan bahwa ukuran diameter silika sebesar 33,412 nm dan kristanilitas yang dimiliki sebesar $89 \%$. Pengaplikasian dari silika dilakukan pada adsorpsi logam $\mathrm{Cu}$ (II) dengan menggunakan AAS, dimana diperoleh daya penjerapan terbesar sebayak $130,725 \mathrm{mg} / \mathrm{g}$ dengan efisiensi penjerapan sebesar 98,66\%.
\end{abstract}

Kata kunci: Silika gel, abu vulkanik, ekstraksi, adsorpsi

\begin{abstract}
Silica gel is one of the silica based material. This research aimed to utilizetion volcanic ash of Sinabung mountains to make silica gel by extraction method. Volcanic ash was extracted using $\mathrm{NaOH} 4 \mathrm{M}$ for 30 , 60, 190 and 120 minutes. Gel was formed by addip $\mathrm{HCl}$ 4, 6,and 8M. Sample were analyzed of using FTIR, SEM-EDX, gravimetri and AAS. Analysis silica sodium solution with concentration variation showed the biggest silica was 120 minutes. FTIR result indicated the presence of $\mathrm{Si}$ in volcanic ash and siloxane (Si-O-Si). SEM-EDX result silica content of silica gel was $51.96 \%$. XRD result showed that diameter of silica was $33.412 \mathrm{~nm}$ and the crystallinity was $89 \%$. Silica was applied on the largest $\mathrm{Cu}$ (II) absorption rate was $130.725 \mathrm{mg} / \mathrm{g}$ with an adsorption efficiency of $98.66 \%$.
\end{abstract}

Key word: Silica gel, volcanic ash, extraction, absorptioni

\section{Pendahuluan}

Potensi sumber daya alam sebagai sumber silika telah banyak diteliti dan diketahui. Silika sebagai salah satu oksida logam yang melimpah di dalam abu vulkanik dapat dimanfaatkan sebagai material dasar sintesis silika gel melalui pembentukan prekursor alkali silikat. Natrium silikat dapat diubah menjadi silika gel dengan proses kondensasi dan hidrolisis menggunakan pelarut, baik polar maupun non polar. Dengan mengekstraksi silika pada keadaan alkali sehingga akan terbentuk natrium silikat. Natrium silikat akan mengalami proses polimerisasi untuk membentuk silika gel pada beberapa perbedaan $\mathrm{pH}$ dan pelarut [5]

Beberapa penelitian tentang pembuatan silika gel telah dilakukan untuk mengkaji tentang ekstraksi silika dari abu sekam padi menggunakan pelarut $\mathrm{NaOH}$. Hasil yang diperoleh bahwa penggunaan pelarut $\mathrm{NaOH}$ yang tinggi akan meningkatkan nilai yield sehingga endapan silika meningkat [16].

Silika gel merupakan salah satu material berbasis silika yang mempunyai kegunaan secara luas seperti pada industri farmasi, keramik, cat, dan aplikasi khusus pada bidang kimia. Silika gel memiliki berat molekul besar dan banyak menyerap air sehingga berbentuk padat kenyal. Silika gel disebut juga silika amorf yang terdiri atas globula-globula $\mathrm{SiO}_{4}$ tetrahedral yang tidak teratur dan beragregat membentuk kerangka tiga dimensi [10] Mengingat begitu banyak manfaat yang dapat diambil dari unsur silika, maka pada penelitian 
kali ini akan dilakukan ekstraksi silika menggunakan metode yang telah dilakukan sebelumnya oleh Ginanjar [16] dengan sampel yang berbeda yaitu abu vulkanik gunung sinabung. Tujuan dari penelitian ini adalah untuk mengetahui pengaruh konsentrasi $\mathrm{HCl}$ pada larutan silika gel yang dihasilkan dan mengetahui daya penyerapan dari silika gel dengan menggunakan logam $\mathrm{Cu}$ (II)

\section{Teori}

Gunung Sinabung merupakan salah satu gunung di dataran tinggi Kabupaten Karo, Sumatera Utara, Indonesia. Koordinat puncak Gunung Sinabung adalah 03o 10' LU dan 98o 23' BT dengan puncak tertinggi gunung ini adalah 2.460 meter dari permukaan laut di Sumatera Utara. Gunung ini belum pernah tercatat meletus sejak tahun 1600 [7]

Letusan gunung api berupa padatan dapat disebut sebagai bahan piroklastik (pyro = api, klastik = bongkahan). Padatan ini berdasarkan diameter partikelnya terbagi atas debu vulkan $(<0.26 \mathrm{~mm})$ yang berupa bahan halus, pasir $(0.25-4 \mathrm{~mm})$ yang berbentuk tumpul, lapilli atau 'little stone' $(4-32 \mathrm{~cm})$ yang berbentuk bulat hingga persegi dan bom (> $32 \mathrm{~mm}$ ) yang bertekstur kasar [2]

Mineral yang paling banyak dalam magma ialah silika $\left(\mathrm{SiO}_{2}\right)$ dan oksigen [14]

Tabel 1. Jenis-jenis mineral dalam abu vulkanik Gunung Sinabung [15]

\begin{tabular}{|l|c|}
\hline \multicolumn{1}{|c|}{ Mineral } & Total (\%) \\
\hline Silika $\left(\mathrm{SiO}_{2}\right)$ & 54,56 \\
Aluminium Oksida $\left(\mathrm{Al}_{2} \mathrm{O}_{3}\right)$ & 18,37 \\
$\mathrm{TiO}_{2}$ & 0,71 \\
$\mathrm{MnO}$ & 0,16 \\
$\mathrm{CaO}$ & 8,05 \\
$\mathrm{MgO}$ & 2,92 \\
$\mathrm{Na}$ & 2,95 \\
$\mathrm{~K}_{2} \mathrm{O}$ & 1,70 \\
$\mathrm{P}_{2} \mathrm{O}_{5}$ & 0,12 \\
Ferri Oksida $\left(\mathrm{Fe}_{2} \mathrm{O}_{3}\right)$ & 8,33 \\
\hline
\end{tabular}

Silika gel adalah senyawa hasil polimerisasi asam silikat yang tersusun secara tidak teratur dari globula - globula rantai satuan $\mathrm{SiO}_{4}$ tetrahedral dan beragregasi membentuk kerangka tiga dimensi yang lebih besar (sekitar $1-25 \mu \mathrm{m})[10]$

Rumus kimia silika gel secara umum adalah $\mathrm{SiO}_{2} \times \mathrm{xH}_{2} \mathrm{O}$. Menurut Oscik (1982), struktur satuan mineral silika gel pada dasarnya mengandung kation $\mathrm{Si}^{4+}$ yang terkoordinasi secara tetrahedral dengan anion $\mathrm{O}^{2-}$, namun susunan $\mathrm{SiO}_{4}$ pada silika gel tidak beraturan seperti terlihat pada gambar 1 [9]

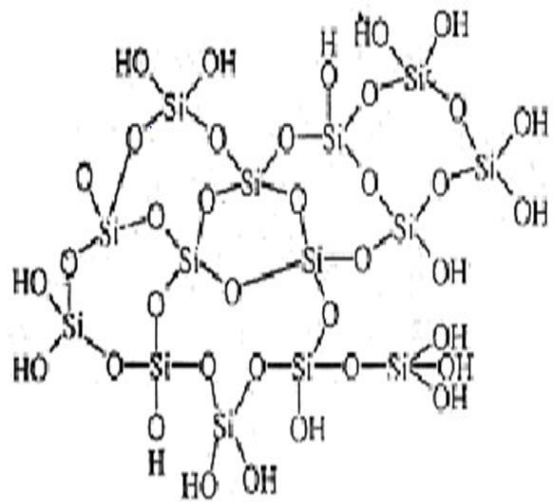

Gambar 1. Struktur silika gel

Pada gambar tersebut menunjukkan bahwa silika gel berasal dari atom silika yang terikat bersama silika lainnya karena adanya ikatan oksigen dengan silokskan (ikatan silikaoksigen-silika) sehingga munculnya gugus $\mathrm{OH}$ yang tidak terkondensasi dari monomer asam silikat.

\section{Metodologi Penelitian \\ Bahan Baku dan Peralatan}

Bahan baku utama dalam penelitian ini adalah abu vulkanik Gunung Sinabung. Peralatan yang digunakan pada penelitian ini adalah hot plate, ayakan 230 mesh, kertas saring, magnetic stirrer, corong, gelas ukur, oven, serta peralatan gelas.

\section{Prosedur Preparasi Abu Vulkanik}

Abu vulkanik diayak dengan ayakan 230 mesh utnuk menghomogenkan ukuran abu. Abu yang telah diayak diambil sebanyak 50 gram dan direndam dengan $\mathrm{HCl}$ dan disaring. Abu kemudian dicuci dan dikeringkan dengan oven.

\section{Prosedur Ekstraksi Larutan Natrium Silika}

Abu vulkanik dilarutkan dengan $500 \mathrm{ml}$ $\mathrm{NaOH} 4 \mathrm{M}$ dan dipanaskan pada variasi waktu (30, 60, 90 dan 120) menit. Disaring untuk megambil filtratnya. Filtrat tersebut diuji dengan garvimetri.

\section{Prosedur Pembuatan Silika Gel}

Larutan natrium silika dimasukkan kedalam beaker glass. Kemudian ditetesi denagn $\mathrm{HCl}$ dengan variasi konsentrasi 4, 6, dan $8 \mathrm{M}$ sampai terbentu gel berwarna putih dengan $\mathrm{pH}$ 7. Silika gel diendakan 24 jam dan disaring sertas dicuci dengan aquadest. Silika gel dikeringkan denagn menggunakan oven. 
Hasil Dan Pembahasan

KARAKTERISASI FOURIER TRANSFORM INFRA - RED (FTIR) ABU VULKANIK GUNUNG SINABUNG

Karakterisasi FTIR (Fourier Transform Infra - Red) abu vukanik gunung Sinabung dilakukan untuk mengidentifikasi gugus fungsi dari abu vulkanik. Karakterisasi FTIR dari abu vulkanik dapat dilihat pada Gambar 2 di bawah ini.

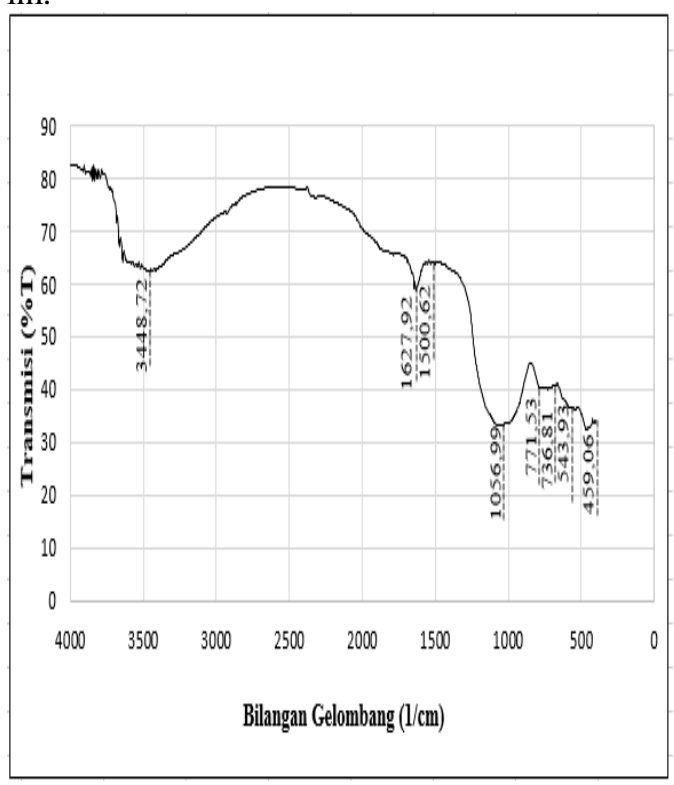

Gambar 2. Uji FTIR abu vulkanik

Uji FTIR yang dilakukan pada abu vulkanik gunung Sinabung pada puncak serapan pada bilangan gelombang 3448,7 $\mathrm{cm}^{-1}$ menunjukan keberadaan gugus hidroksil $(-\mathrm{OH})$ yang berikatan dengan Si membentuk Silanol (Si-OH), serapan pada bilangan gelombang $1627,92 \mathrm{~cm}^{-1}$ menunjukkan keberadaan gugus hidroksil $(\mathrm{OH})$ dari molekul air. Serapan pada bilangan gelombang $1500,62 \mathrm{~cm}^{-1}$ dan 1056,99 $\mathrm{cm}^{-1}$ menunjukkan keberadaan gugus fungsi siloksan (Si-O-Si). Serapan pada bilangan gelombang 771,36 $\mathrm{cm}^{-1} ; 736,81 \mathrm{~cm}^{-1} ; 543,93$ $\mathrm{cm}^{-1}$ dan 459,06 $\mathrm{cm}^{-1}$ menunjukkan keberadaan gugus fungsi $\mathrm{Si}-\mathrm{O}$ [4]

Dari hasil karateristik FTIR pada abu vulkanik gunung sinabung menunjukkan adanya kandungan silika, hal ini dapat dilihat pada gugus fungsi silanol, siloksan dan Si-O, sehingga fari gugus fungsi tersebut dapat disimpulkan bahwa abu vulkanik gunung Sinabung dapat dapat dijadikan sebagai sumber pembuatan silika gel.

\section{PENGARUH WAKTU EKSTRAKSI TERHADAP KADAR SILIKA}

Pengaruh waktu ekstraksi terhadap kandungan silika yang dihasilkan dari larutan natrium silika dapat dilihat pada gambar 3 dibawah ini.

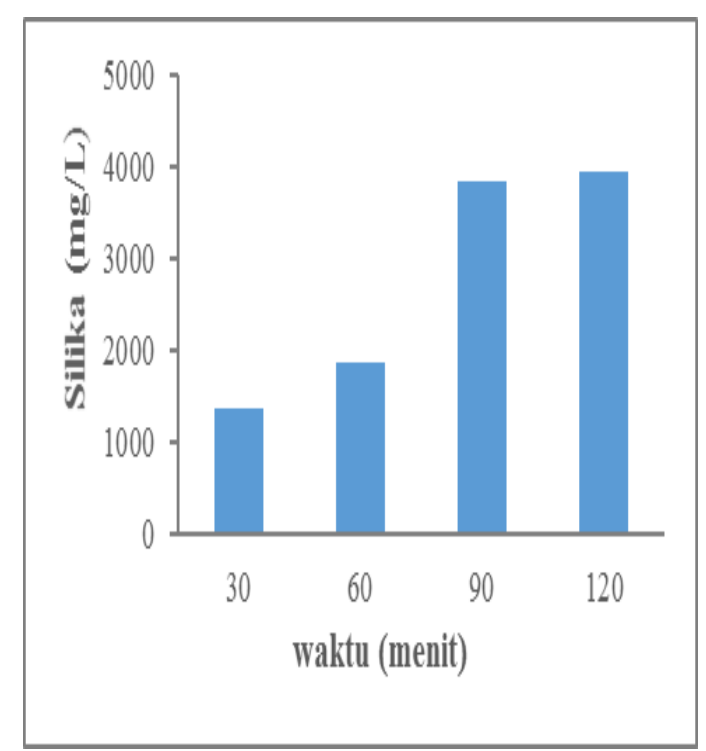

Gambar 3. Pengaruh waktu terhadap silika

Pada ekstraksi padat-cair, ketika bahan ekstraksi dicampur dengan ekstraktan maka ekstraktan akan bereaksi dengan bahan padat membentuk ekstrak. Dalam proses ekstraksi padat-cair diperlukan kontak yang sangat lama antara ekstraktan dan padatan [12]. Dari Gambar 3. dapat dilihat bahwa pada penelitian ini dilakukan variasi waktu ekstraksi sebesar (30, 60, 90 dan 120) menit dimana pada penelitian ini diperoleh kandungan silika yang optimum pada larutan natrium silika berada pada waktu 120 menit menghasilkan sebesar 3957,70 mg/L silika.

Secara umum semakin lama waktu kontak maka interaksi anatar silika dan $\mathrm{NaOH}$ semakin besar pula, sehingga semakin banyak silika yang terekstrak. Hal ini disebabkan karena semakin lama waktu kontak maka reaksi antara silika dengan $\mathrm{NaOH}$ akan semakin besar sehingga akan semakin banyak silika yang terekstrak. Tetapi apabila mencapai waktu optimum maka silika terekstrak akan cenderung menurun karena pelarut telah mengalami kejenuhan. Hasil diatas juga diperkuat oleh penelitian pada silika yang berasal dari abu terbang batu bara yang dilakukan oleh Aman dan Panca dimana kondisi terbaik berada pada waktu 4 jam menghasilkan silika sebanyak $3,08 \%$ [1]. Pada penelitian

Hasil dari penelitian ini telah sama dengan hasil penelitian sebelumnya dimana pada penelitian ini diperoleh semakin lama waktu yang digunakan maka akan menghasilkan kandungan silika yang semakin besar pula. 


\section{PENGARUH KONSENTRASI HCL TERHADAP BERAT SILIKA}

Pengaruh konsentrasi $\mathrm{HCl}$ terhadap berat silika gel yang dihasilkan dapat dilihat pada gambar 4 dibawah ini.

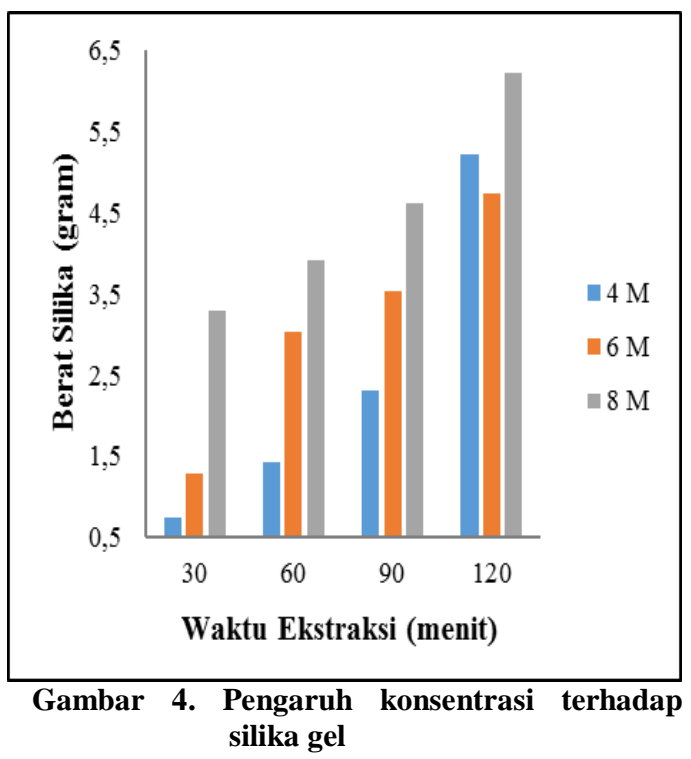

Dari gambar 4 terlihat bahwa silika gel yang diperoleh cenderung mengalami kenaikan seiring dengan bertambahnya konsentrasi $\mathrm{HCl}$. Pada penelitian ini diperoleh berat silika terendah berada pada waktu 30 menit dengan konsentrasi $4 \mathrm{M}$ sebesar 0,75 gram dan berat silika tertinggi diperoleh pada waktu 120 menit dengan konsentrasi 8M sebesar 6, 22 gram.

Penambahan $\mathrm{HCl}$ pada sintesis gel silika mengakibatkan terjadinya pembentukkan gugus siloksan (Si-O-Si), sehingga dihasilkan gel silika yang kaku. Pembentukkan gugus siloksan terjadi karena pada saat larutan natrium silikat ditambah $\mathrm{HCl}$, gugus $-\mathrm{OH}$ dari silanol $(\mathrm{Si}-\mathrm{OH})$ yang terbentuk mengalami hidrasi dan membentuk ${ }^{+} \mathrm{OH}_{2}$. Hal ini akan memudahkan gugus -OH dari $\mathrm{Si}-\mathrm{OH}$ yang lain untuk mensubstitusi ${ }^{+} \mathrm{OH}_{2}$ yang hilang membentuk gugus/ikatan siloksan (Si-O-Si) [3]. Hasil diatas juga diperkuat oleh penelitian pada silika dengan bahan dasar pasir kuarsa oleh Meirawati dimana kondisi optimum diperoleh pada konsentrasi 0,5M [4] dan pada penelitian Sholika diperoleh konsetrasi optimum berada pada 5M [8]

Sintesis silika gel dengan menggunakan larutan asam klorida dengan konsentrasi kecil, akan menghasilkan gel yang sedikit dan pembentukan gelnya membutuhkan waktu yang lama. Hal ini disebabkan karena rendahnya konsentrasi proton dari larutan asam klorida sehingga jumlah asam silikat yang terbentuk juga sedikit yang mengakibatkan rendahnya efektifitas produksinya. Sebaliknya sintesis silika gel menggunakan larutan asam klorida dengan konsentrasi besar maka reaksi pembentukan gel sangat cepat [8]

Secara garis besar, hasil penelitian yang diperoleh menunjukkan bahwa semakin besar konsentrasi yang diberikan maka berat silika gel yang dihasilkan akan semakin banyak.

\section{KARAKTERISASIFOURIER TRANSFORM INFRA - RED (FTIR) SILIKA GEL}

Karateristik FTIR silika gel dapat dilihat pada gambar 5 di bawah ini.

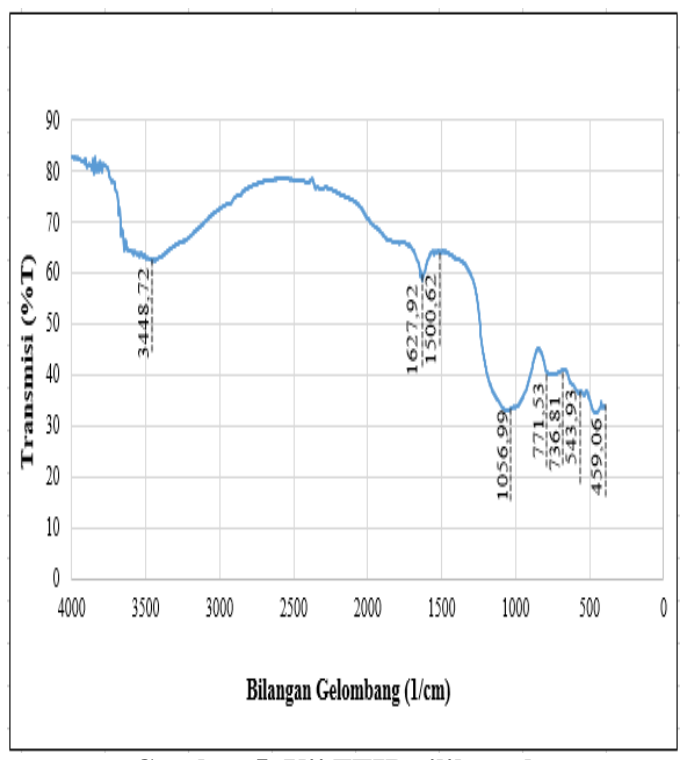

Gambar 5. Uji FTIR silika gel

Karateristik FTIR diatas menunjukan beberapa puncak serapan yang dapat mengidentifikasi suatu gugus sebagai ciri khusus dari suatu senyawa. Uji FTIR yang dilakukan pada silika gel diperoleh puncak serapan pada bilangan gelombang $3437,15 \mathrm{~cm}^{-1}$ menunjukan keberadaan gugus fungsi silanol yang berasal dari ikatan gugus hidroksil denagn $\mathrm{Si}$, serapan pada bilangan gelombang 1635,64 $\mathrm{cm}^{-1}$ menunjukkan keberadaa gugus hidroksil $(\mathrm{OH})$, serapan pada bilangan gelombang $1064,71 \mathrm{~cm}^{-1}$ menunjukkan keberadaan gugus fungsi siloksan ( $\mathrm{Si}-\mathrm{O}-\mathrm{Si}$ ), serapan pada bilangan gelombang 705,95 $\mathrm{cm}^{-1}$ dan 455, $20 \mathrm{~cm}^{-1}$ menunjukkan keberadaan gugus fungsi Si-O.

Berdasarkan penelitian yang telah dilakukan Kurniati, 2009 terhadap silika gel komersil (Silika gel 60 Merck) maka diperoleh puncak serapan kunci pada bilangan gelombang $3433,39 \mathrm{~cm}^{-1} ; 1087,85 \mathrm{~cm}^{-1} ; 910,40 \mathrm{~cm}^{-1}$; $802,39 \mathrm{~cm}^{-1}$ dan $470,63 \mathrm{~cm}^{1}$ [6] 
Dari hasil penelitian diperoleh intensitas gugus silanol $(\mathrm{Si}-\mathrm{OH})$ yang mendekatai gugus silanol pada silika gel 60 Merk yaitu sebesar $3437,15 \mathrm{~cm}^{-1}$ dan $3433,39 \mathrm{~cm}^{-1}$. Namun silika gel dari hasil penelitian tersebut masih mengandung air yang ditunjukkan dengan munculnya gugus fungsi $1635,64 \mathrm{~cm}^{-1}$. Berbeda dengan kiesel gel 60 Merk yang hanya menghasilkan gugus fungsi silanol (Si-OH), siloksan (Si-O-Si) dan $\mathrm{Si}-\mathrm{O}$

\section{KARAKTERISASI $X$-RAY DIFFRACTION (XRD) SILIKA GEL}

Hasil dari pengujian kristalinitas menggunakan XRD dapat ditunjukan oleh gambar 6 dibawah ini.

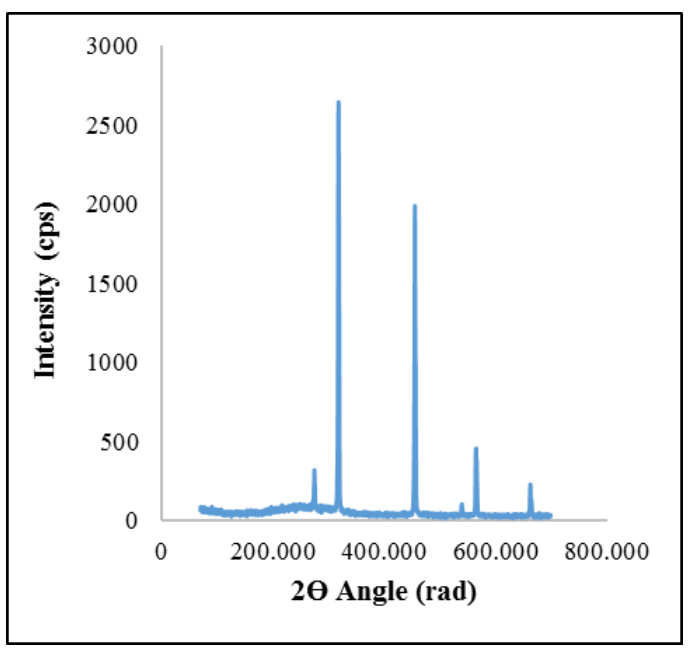

Gambar 6. Karateristik XRD

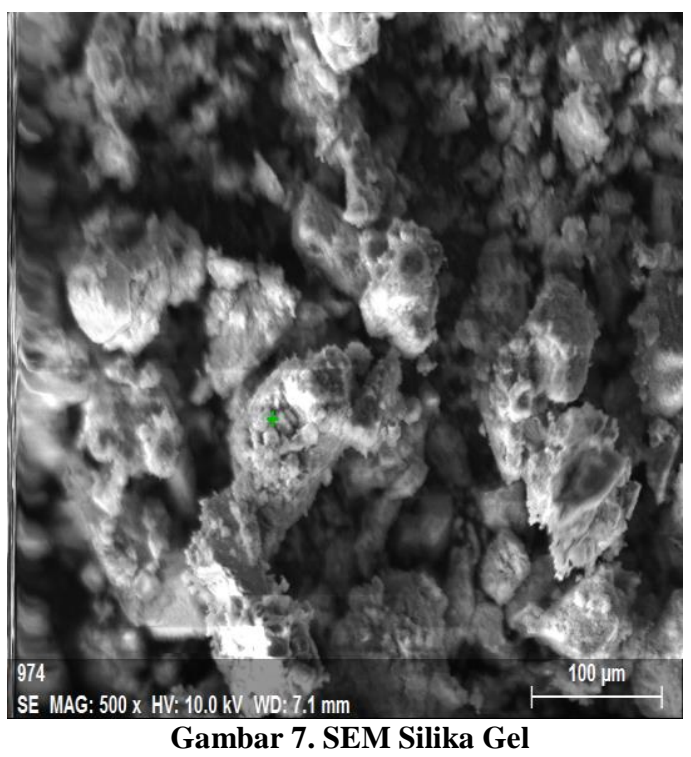

Dari gambar 6 dapat ditentukan index kristalinitasnya $(\mathrm{Cl} /$ The Crystallinity Index), penentuan index kristalinitas suatu bahan dapat dilakukan dengan menggunakan metode sehingga diperoleh kritanilitas sebesar $89 \%$ dan diameter 33,44 nm.

Pada penelitian ini terlihat dengan jelas bahwa permukaan sampel tidak merata dan terdiri dari gumpalan, yang memperlihatkan adanya ukuran butir yang cukup beragam dengan distribusi yang tidak merata pada permukaan. Pemisahan antara gumpalan juga terlihat dengan cukup jelas, yakni dalam bentuk micro-cracking yang terdapat di antara cluster. Hal ini di dukung oleh hasil analisa XRD yang menunjukkan bahwa silika yang terbentuk bersifat kristobalit

Untuk mengetahui komposisi unusr dari silika gel yang dihasilkan dapat dilakukan dengan menggunakan EDX. Pada gambar 7 merupan hasil karaterisasi silika dengn EDX

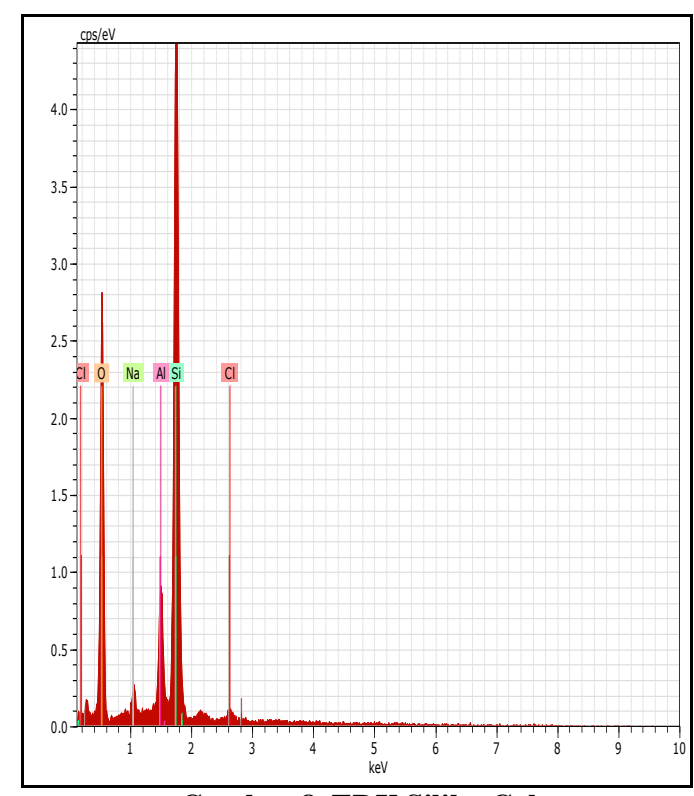

Gambar 8. EDX Silika Gel

Informasi tambahan yang didapatkan dari analisis dengan SEM adalah data EDS, yang menunjukkan unsur-unsur yang terdapat dalam sampel serta komposisi sampel berdasarkan unsur tersebut. Hasil yang diperoleh disajikan pada Gambar 4.7, yang menunjukkan terdapatnya berbagai unsur kimia dalam sampel, meliputi O sebesar 39,74\%, Na sebesar 1,08\%, Al sebesar 6,21\%, dan $\mathrm{Cl}$ sebesar $1,01 \%$. Selain menunjukkan kemungkinan fase yang terdapat dalam sampel, hasil analisis EDS juga menunjukkan bahwa kemurnian silika gel dalam sampel adalah sebesar 51,96\%. Berdasarkan penelitian yang dilakukan oleh Nakada dan Yoshimoto bahwa pada abu vulkanik gunung Sinabung terkandung sebesar 57, 01\% silika [13], sehingga dari penelitian yang dilakukan berdasarkan 
karateristik SEM-EDX diperoleh kandungan silika yang hampir mendekati penelitian terdahulu.

\section{Kesimpulan}

1. Silika gel dapat diekstraksi dari abu vulkanik gunung Sinabung. Hasil uji dengan gravimetri menunjukan bahwa pada kandungan silika tertinggi pada larutan natrium silika berada pada waktu 120 menit yaitu sebesar 3957, $70 \mathrm{mg} / \mathrm{L}$

2. Massa silika terbanyak terdapat pada konsentrasi $\mathrm{HCl} 8 \mathrm{M}$, dimana menghasilkan silika sebesar 6,22 g

3. Hasil uji XRD memberikan hasil indeks kristalinitas sebesar $89 \%$ dan diameter silika gel sebesar $33,412 \mu \mathrm{n}$

4. Daya penjerapan dan efesiensi penjerapan terhadap ion logam $\mathrm{Cu}(\mathrm{II})$ optimal diperoleh pada waktu ekstraksi 120 menit dengan konsentrasi 4M

5. Hasil uji SEM-EDX memberikan hasil unsur silika yang terdapat pada abu vulkanik gunung Sinabung sebesar 51,96\%

\section{Daftar Pustaka}

[1] A. Prastiyanto, C. Azmiyawati, dan A. Darmawan, Pengaruh Penambahan Merkaptobenzotiazoi (MBT) Terhadap Kemampuan Adsorpsi Gel Silika Dari Kaca Pada Ion Logam Kadmium, Skripsi, Universitas Diponegoro, Semarang, 2008.

[2] B. I. L. J. Sinaga, M. Sembiring dan A. Lubis, Dampak Ketebalan Abu Vulkanik Erupsi Gunung Sinabung Terhadap Sifat Biologi Tanah Dikecamatan Naman Teran Kabupaten Karo, Jurnal Online Agroekoteknologi, Vol 3, No. 3, ISSN: 2337-6597, (2015), 1159-1163.

[3] Badan Standaeisasi Nasional, SNI 062477-1991, http://sisni.bsn.go.id, 2013, diakses pada tanggal 2 Oktober 2017

[4] D. Meirawati, S. Wardhani dan R. Triandji, Studi Pengaruh Konsentrasi $\mathrm{HCl}$ Dan Waktu Aging (Pematangan Gel) Terhadap Sintesis Silika Xerogel Berbahan Dasar Pasir Kuarsa Bangka, Kimia Student Journal, Vol 2 (2), (2013), 524-531.

[5] D. R. Uhlman, dan N. J. Kreidhl, Glass Sciences and echnology, Penerbit Academi Press, 1980, p. 360.

[6] E. Kurniaty, Ekstraksi Silica White Powder dari Limbah Padat Pembangkit Listrik Tenaga Panas Bumi Dieng, Penerbit UPN Press, 2009.
[7] Global Volcanism Program, Sinabung, http://www.volkanosi.edo.com, 2008, diakses pada tanggal 5 agustus 2016

[8] I. Sholikha, Friyatmoko, E. D. S. Utami, Listyanti, W. Dianingsih, Sintesis Dan Karateristik Silika Gel Dari Limbah Abu Sekam Padi Dengan Variasi Konsentrasi Pengasaman, Skripsi, Universitas Negeri Yogyakarta, Yogyakarta, 2015

[9] J. Oscik, Adsorption, Penerbit Elis Horwood, 1982, p 185

[10] K. G. Patel, N. M. Misra, dan R. R. Shetiggar. Preparation and Characterization Of Silica Gel From Wheat Straw. Journal Chemical Engginering and Application. (October, 2016), Vol. 7, No. 5

[11] R. M. Silverstein, G. C. Basslerr, and T. C. Morrill, Spectrometric Identification of Organic Compound", 4th edition, John Wiley and Sons, Ney York. 1981

[12] R. R. Ginanjar, A. Maruf dan A. H. Mulyadi, Ekstraksi Silika Dari Abu sekam Padi Menggunakan Pelarut $\mathrm{NaOH}$, Prosiding Seminar Hasil, 2014

[13] S. Nakada, dan M. Yoshimoto, Eruptive Activity Of Sinabung Volcano In 2013 And 2014, Earthquake Research Institute, University Tokyo. 2014.

[14] Sudarmadji dan Hamdi, Pengaruh Penggunaan Abu Vulkanik Sebagai Filer Terhadap Campuran Aspal Beton Lapis Asphalt Concrete- Wearing Course. Jurnal Teknik Sipil, Vol. 10, No. 2, ISSN: 1907-6975,(2014).

[15] W. A. A. Sudjarwo, I. Y. M. Wibowo, dan D. K. Dipayana, Sintesis Silika Gel Dari Abu Vulkanik Gunung Merapi. Seminar Nasional Teknologi Kimia, Industri dan Informasi, Universitas Setia Budi Surakarta, 2015. 